Ann. Biol. anim. Bioch. Biophys., 1978, 18 (1), 53-68.

\title{
Calcitonin in the mother, fetus and newborn
}

par J.-M. GAREL, J.-P. BARLET *

Physiologie du Développement, Université Pierre ef Marie Curie

9. Quai Saint-Bernard, 75230 Paris Cedex 05

* Laboratoire des Maladies métaboliques, I.N.R.A.

Theix, Saint-Genès-Champanelle 63110 Beaumont, France.

Summary. The high plasma calcitonin level in the mother during gestation and lactation protected the maternal skeleton against excessive demineralization. The relative independence of fetal calcemia from the maternal plasma calcium concentration was well established and the concept of hormonal autonomy of fetal secretion of parathyroid hormone and calcitonin developed. However, the role of these hormones during fetal life remained obscure. A new aspect of calcitonin physiology in the newborn, the regulation of nutrient absorption through gastric emptying, is mentioned.

\section{The mother.}

Calcium needs are increased in the female during gestation and lactation. Comar (1956) has shown that the transfer of calcium through the placenta and the mammary gland is greatest at the end of gestation and during lactation, respectively. Kinetic studies using calcium 45 demonstrated that fetal and newborn calcium contents were originated from maternal intestinal absorption and/or maternal skeleton, the relative importance of the two contributions being species-dependent. According to Wasserman ef al. (1957), 92 p. 100 of the fetal calcium in rat is of maternal dietary origin. In contrast, intestinal calcium absorption in ruminants is not sufficient to cover the calcium needs of the fetus or of the newborn in lactating cows (Symonds ef al., 1966) and in pregnant ewes (Braithwaite, Glascock and Riazuddin, 1969 ; Braithwaite, Glascock and Riazuddin, 1970), the calcium being supplied by maternal bone resorption.

In many species, the intestinal absorption increases. Chef (1969) observed a sharp inc rease of intestinal calcium absorption in pregnant rat during the last three days of gestation. According to Heaney and Skillman (1971), intestinal calcium absorption in humans was twice the normal level from the fifth week of pregnancy, and remained high throughout pregnancy. In ewes, the rate of calcium absorption from the intestine increase steadily throughout pregnancy and reached a maximum during lactation (Braith waite, Glascock and Riazuddin, 1970). According to the same authors, the rate of bone resorption in ewes increased rapidly in late pregnancy and reached a maximum at parturition. 
Parathyroid hormone which stimulates bone resorption and intestinal absorption through vitamin $D$ metabolites may be responsible for these physiological changes. Indeed, the works of Cushard ef al. (1972) and of Bouillon and De Moor (1973) show that the plasma levels of immunoreactive parathyroid hormone increased during the last three months of pregnancy in humans. In cows fed a normal calcium diet, plasma parathyroid hormone levels were very high in the last two months of gestation (Black, Capen and Arnaud, 1973).

Thus, it is tempting to speculate that a factor might regulate the loss of calcium from the maternal skeleton during gestation and lactation. Calcitonin (CT), a hypocalcemic and hypophosphatemic hormone, acts by inhibiting bone resorption and these effects are more intense as bone resorption is enhanced. The role of CT might be important during gestation and lactation, as proposed by Konopka, Klotz and Delorme (1971) and suggested the same year by Lewis ef al. (1971). We have shown that the jugular venous plasma CT concentrations (fig. 1) were higher in pregnant ewes than
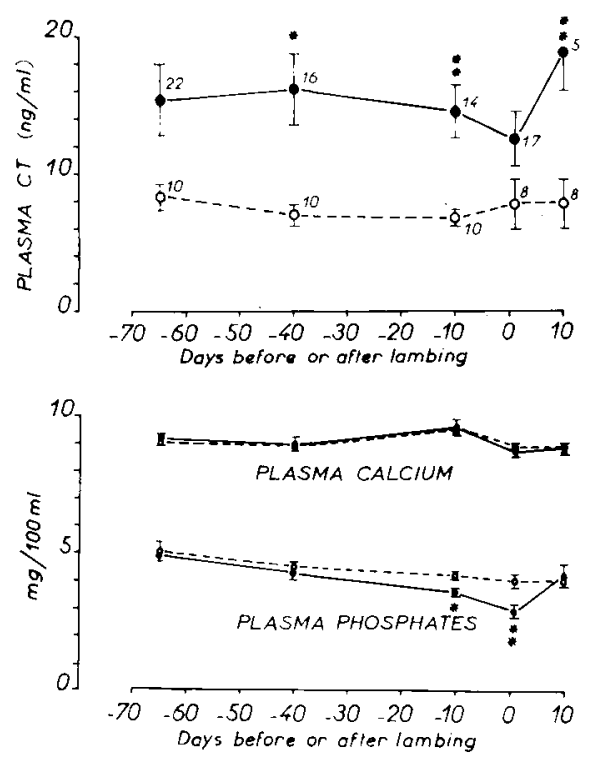

FIG. 1. - Changes in jugular venous plosma concentrations of calcium, inorganic phosphorus and calcitonin during gestation, parturition and lactation in ewes. Means \pm SEM. Number of estimations as integer. Significance of difference between control (0) and pregnant ewes ( $\bullet$ ) was studied by Student's test $* \mathrm{P}<0.05 ;{ }^{*} \mathrm{P}<0.01$.

(From Garel, Savajol and Barlet, 1976.)

in control animals at the end of gestation and during lactation in spite of the absence of any difference in plasma calcium levels. The highest CT levels were measured in animals bearing triplets in which the rate of placental transfer of calcium is very high : $5.4 \mathrm{~g} /$ day versus $1.7 \mathrm{~g} / \mathrm{day}$ in animals bearing a singleton (Field and Suttle, 1967). In thyroidectomized goats supplemented with thyroxin and fed a high calcium diet, the 
calcium and phosphate contents of bones (fig. 2) were significantly lower than in control goats. However, the calcium and phosphate contents of fefal bones from CTdeficient goats were significantly higher than those of fetuses from control goats (fig. 2). This last observation might indicate a higher placental transfer of calcium in CT-deficient goats due to suppression of an inhibitory effect of maternal CT on the placental calcium pump. These data strongly suggest that one physiological role for the high CT levels involves the protection of the ruminant female against excessive bone resorption during pregnancy and lactation. In humans, plasma CT levels are higher at the end of pregnancy than those found at the beginning or in non-pregnant women (Samaan, Wigoda and Castillo, 1974). A protective effect of CT on the maternal skeleton of pregnant rats has also recently been described (Taylor, Lewis and Balderstone, 1975).

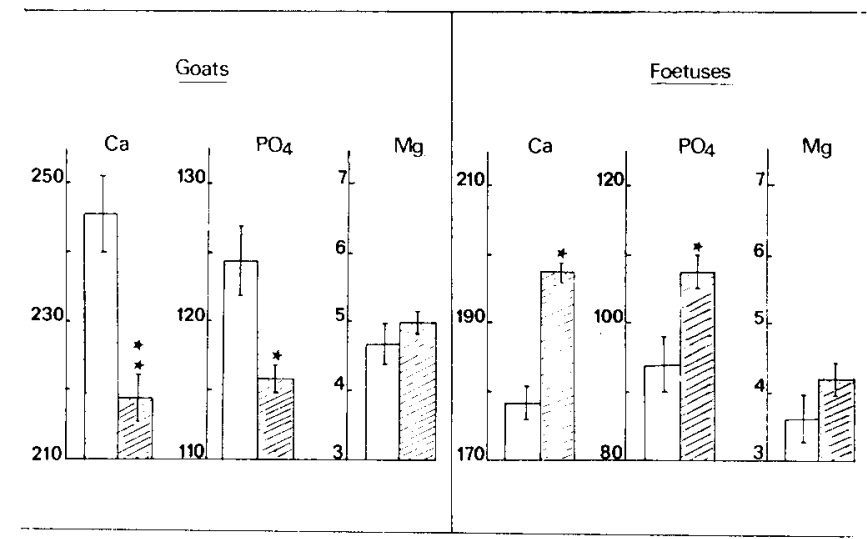

FIG. 2. - Calcium, phosphate and magnesium content of bones $(\mathrm{mg} / \mathrm{g}$ of dried defatted bone) from intact

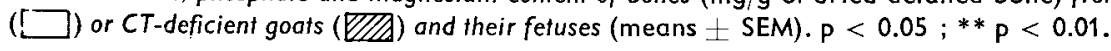

(From Barlet and Garel, 1975.)

\section{The fetus.}

Plasma calcium concentration is higher in the mammalian fetus than in the mother at the end of gestation. Higher ultrafiltrable and ionized plasma calcium concentrations were also reported in the fetus at the end of gestation (Bawden, Wolkoff and Flowers, 1965 ; David and Anast, 1974 ; Delivoria-Papadopoulos et al., 1967 ; Radde, Parkinson and Hoffken, 1971). The factors which maintain this chemical gradient are still poorly understood. Bakwin (1937) postulated that the placental transfer of maternal parathyroid hormone may explain fetal hypercalcemia, but we have shown that the 1-84 bovine peptide did not cross the placenta near term in rats (Garel and Dumont, 1972). Salmi (1954) suggested that fetal blood acidosis was a contributing cause and Delivoria-Papadopoulos ef al. (1967) attributed a role to the greater calcium affinity of fetal plasma proteins. A calcium-dependent ATPase has been isolated from placental membranes (Shami and Radde, 1971) but there is actually no evidence that this enzyme is involved in the placental transfer of calcium. The existence of a placental 
calcium-binding protein cannot be excluded, but as yet such a molecule has not been described. In one species, the rat, several lines of evidence suggest that the fetal parathyroid glands may partly control fetal calcemia. A fall in plasma calcium occurs in the rat fetus after thyroparathyroidectomy or the injection of antibovine-PTH serum (Garel, 1970a ; Pic, Maniey and Jost, 1965 ; Pic, 1973) which is corrected by parathyroid extract injection (Garel, Pic and Jost, 1971) (table 1). Thyroparathyroidectomy in rat fetus delayed recovery from EDTA-induced hypocalcemia (Garel, 1975). Higher calcemia in the fetus than in the mother in thyroparathyroidectomized rat fetus from thyroparathyroidectomized mother (Pic, 1968) demonstrated that the plasma calcium level in rat fetus depends primarily on the calcium flux through the placenta. However, the fetal parathyroid glands also contribute $1-2 \mathrm{mg} / 100 \mathrm{ml}$ to the maintenance of plasma calcium level in the fetal rat.

\section{TABLE 1}

Plasma calcium and magnesium concentrations af 21.5 days of gestation in rat fetuses, thyroparathyroidectomized (TPTX by decapitation), TPTX injected with parathyroid extract (PTE), or infact.

\begin{tabular}{|c|c|c|c|c|}
\hline & \multicolumn{3}{|c|}{ Fetuses } & \multirow[t]{2}{*}{ Mothers } \\
\hline & Intact & Decapitated & $\begin{array}{c}\text { Decapitated } \\
\text { + PTE }\end{array}$ & \\
\hline $\begin{array}{l}\text { Calcemia }(\mathrm{mg} / 100 \mathrm{ml}) \ldots \ldots \\
\text { Magnesemia }(\mathrm{mg} / 100 \mathrm{ml}) \ldots\end{array}$ & $\begin{array}{c}11.50 \pm 0.60 \\
(13) \\
2.40 \pm 0.10 \\
(10)\end{array}$ & $\begin{array}{c}10.20 \pm 2.32 * * * \\
(5) \\
2.00 \pm 0.06 * * \\
(15)\end{array}$ & $\begin{array}{c}12.20 \pm 0.23 * * * \\
(20) \\
1.88 \pm 0.14 \\
(7)\end{array}$ & $\begin{array}{c}10.00+2.21 \\
1.77+0.08 \\
(13)\end{array}$ \\
\hline
\end{tabular}

Means \pm SEM ; ${ }^{* *} \mathrm{P}<0.01 ; * * * P<0.001$.

Although the fetus is completely dependent on its dam for calcium supply, fetal calcemia appears relatively independent from maternal calcemia. Krukowski and Lehr (1963) demonstrated that an increase in maternal calcemia induced by parathyroid extract injection did not change fetal calcemia in rat. The relative autonomy of the fetus in regard to the control of its plasma calcium suggests a hormonal autonomy which was already investigated for parathyroid hormone in the work of Smith ef al. (1972) using sheep fetus near term. Our results confirm this first report ; EDTA infusion 10 days before term in pregnant ewes decreased the maternal unchelated plasma calcium level without changing the fetal level (fig. 3). Maternal hypocalcemia was associated with an increase in the plasma parathyroid hormone level, whereas in the fetus plasma parathyroid hormone levels were undetectable throughout the experiment (fig. 3). EDTA infusion into the sheep fetus, however, increased the fetal plasma parathyroid hormone level in response to hypocalcemia (fig. 4).

Plasma calcium, magnesium and inorganic phosphorus concentrations in the fetus.

A higher plasma calcium level in the fetus than in the mother suggests a high CT secretion rate since it has been shown in adults by Care et al. (1968) that CT secretion is 


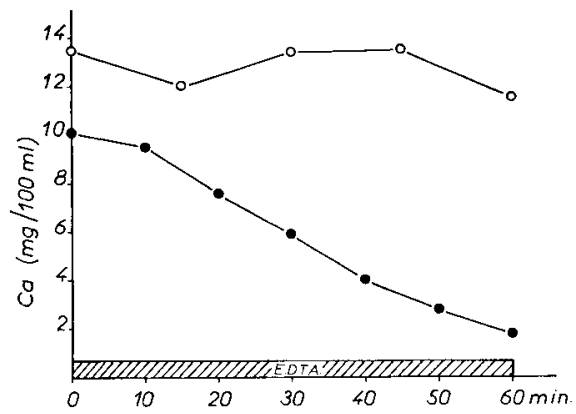

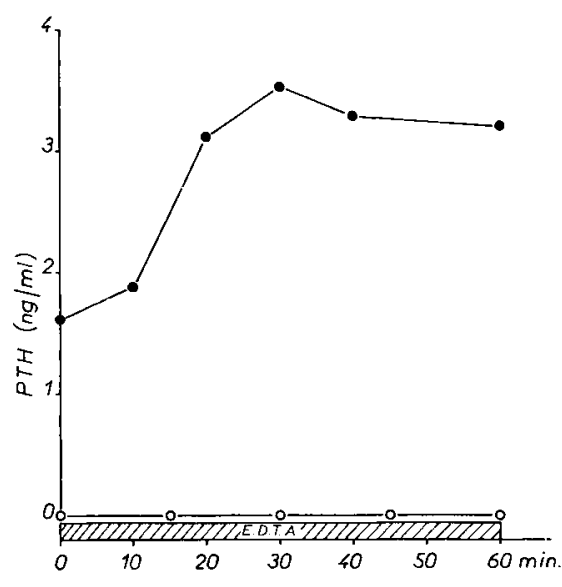

FIG. 3.
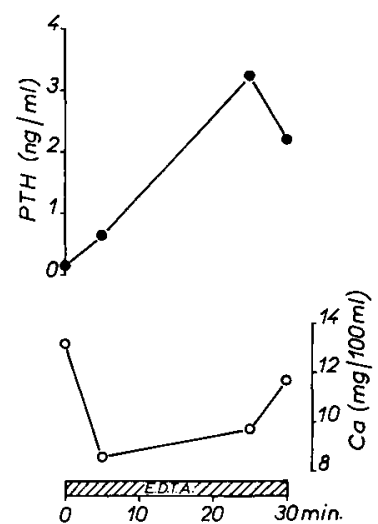

FIG. 4.

FIG. 3. - Changes in unchelated plasma calcium concentrations (Ca) and parathyroid hormone levels $(P T H)$ in mother (๑) and foetus (o) after intravenous infusion of EDTA into the pregnant ewe.

(Adapted from Care ef al., 1975.)

FIG. 4. - Change in plasma immunoreactive parathyroid hormone leve/s (PTH) in sheep fetus after infusion of EDTA into the fetus.

directly proportional to calcemia. However, little is known about the developmental changes of plasma calcium in the fetus throughout gestation. For this purpose, the plasma levels of calcium, magnesium, inorganic phosphorus and total proteins were investigated throughout the last week of gestation in rats. At each stage studied, fetal rat calcemia was higher than in the mother during the last 6 days of gestation (Pic, 1969). The simultaneous developmental changes in proteinemia (Garel and Barlet, 1974) indicated that high calcium affinity of fetal proteins was probably not involved in fetal hypercalcemia since fetal plasma protein level was extremely low at the earliest stage studied (16.5 days). Moreover, there is no correlation between fetal calcemia and fetal proteinemia during the last week of gestation (Garel and Barlet, 1974). Thus, it may be possible that ultrafiltrable and ionized plasma calcium fractions would be very high in early fetal like. Similar findings of high plasma calcium levels asso- 
ciated with extremely low levels of plasma protein were already reported in 28-day old guinea-pig (Graham and Scothorne, 1970) and in 16-day old rabbit fetus (Graham and Porter, 1971). Fetal plasma magnesium values would lead to the same conclusions since they are higher in the fetus than in the mother at each stage studied (Garel and Barlet, 1974), the highest level being observed in 16.5-day old rat fetus. Plasma level of inorganic phosphorus was also higher in the fetus than in the mother during the last week of gestation in rats (Garel and Pic, 1972). Using sheep or calf fetus with chronically implanted catheters placed early in ufero we have also shown that the plasma concentrations of calcium and inorganic phosphorus were higher in the fetus than in the mother one week before term (fig. 5) (Barlet ef al., 1976). There is a decrease in plasma concentrations of calcium, magnesium and inorganic phosphorus in rat fetus between 16.5 and 17.5 days of gestation with the onset of fetal ossification (Jost, Moreau and Fournier, 1960). Such decreases in plasma calcium at that time of fetal ossification are also observed in guinea-pig and rabbit fetuses (Graham and Scothorne, 1970 ; Graham and Porter, 1971), but the shifts are greater. The subsequent increase

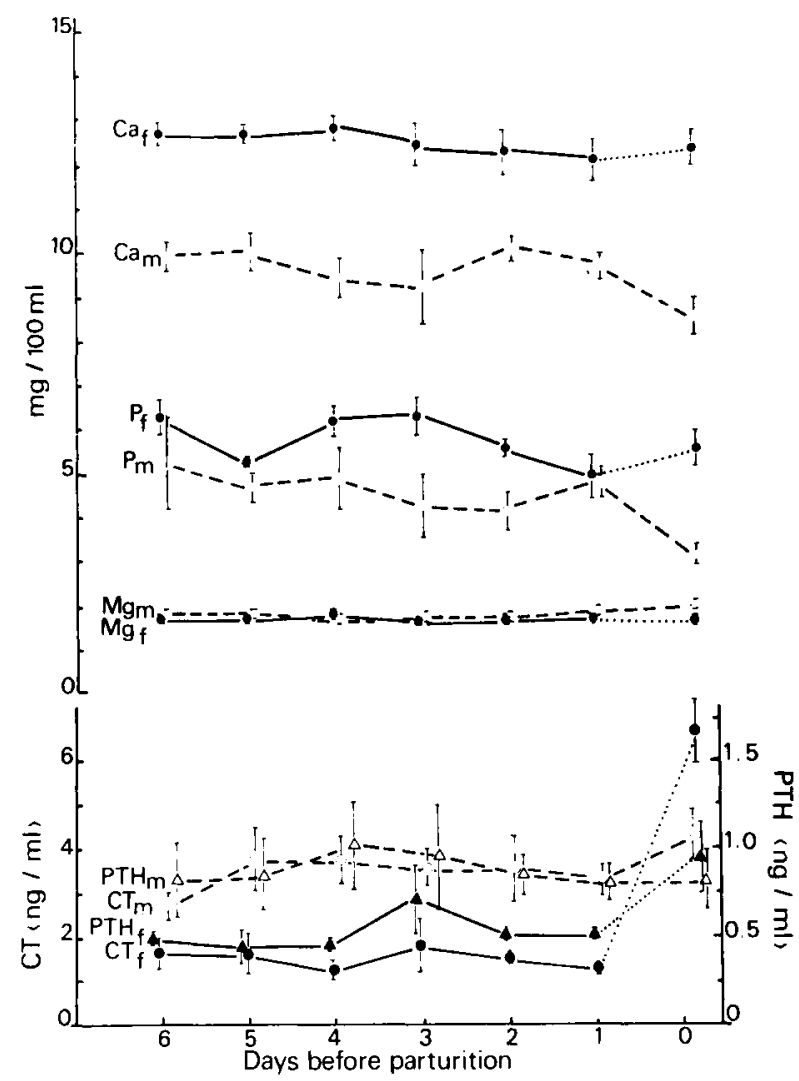

FIG . 5. - Changes in plasma concentrations of calcium $(C a)$, inorganic phosphorus $(P)$, magnesium $(M g)$, calcitonin $(C T)$ and parathyroid hormone $(P T H)$ in conscious mother $(0---0)(m)$ and calves fetus $(\bullet-\infty)$ (f) with chronic catheters implanted early in utero. Each point represents the mean value for 4 animals. 
in plasma calcium is probably due to the onset of fetal parathyroid gland function. The simultaneous decrease in plasma calcium and magnesium concentrations between 19.5 and 21.5 days of gestation in rat fetus suggests the onset of thyroid $《 C$ » cell function.

Effects on fetal blood concentrations of changes in maternal calcemia, phosphatemia and magnesemia.

An acute maternal hypercalcemia induced by the intraperitoneal injection of calcium gluconate in 21.5-day old pregnant rats slightly increased fetal calcemia (fig. 6). Thyroparathyroidectomy of pregnant rats on the third day of gestation sharply decreased and increased the plasma concentrations of calcium and phosphate, respectively, at 21.5 days of gestation in the mother but induced the same variations to

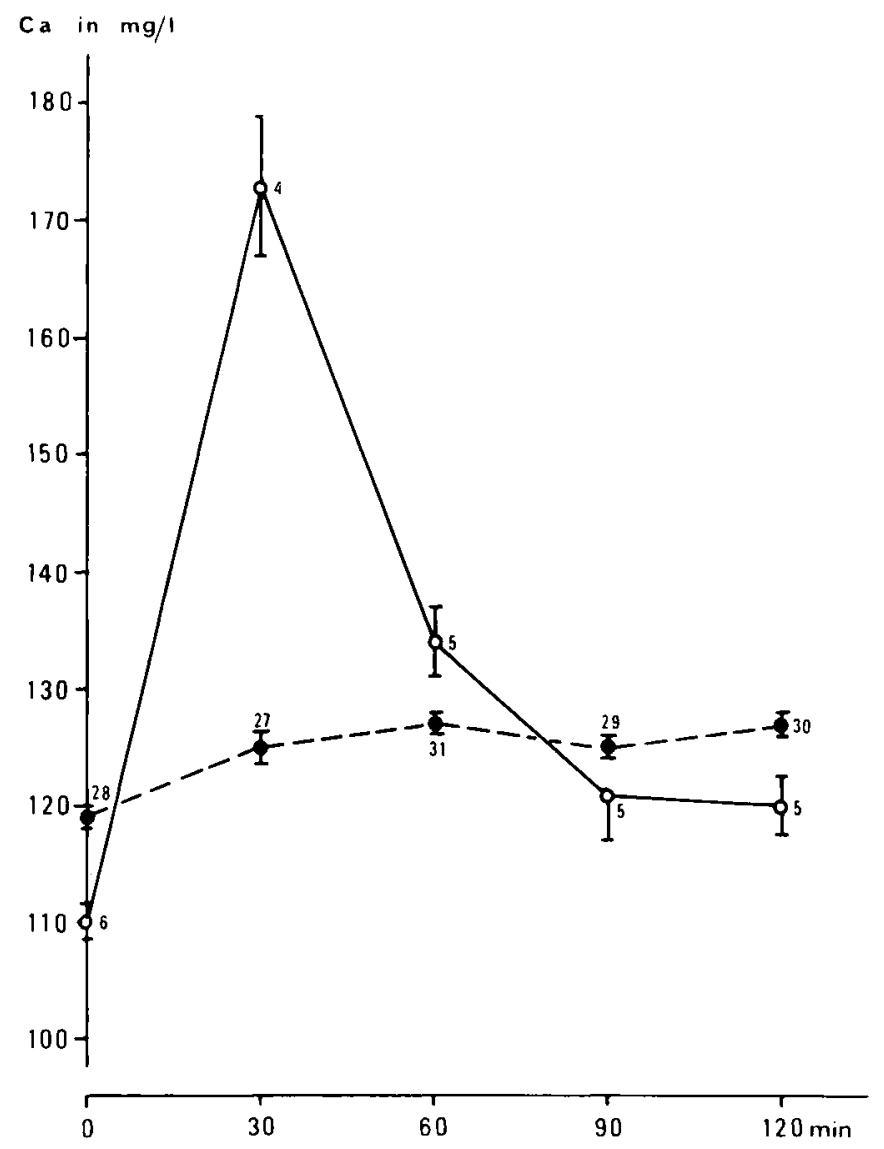

FIG. 6. - Iniraperitoneal injection of a single dose of calcium ( $3 \mathrm{mg} \mathrm{Ca} / 100 \mathrm{~g} \mathrm{~b}$. w.) into the mother (black line) ; effect on fetal rat calcemia (dotted line) (means \pm SEM).

(From. Garel et ol., 1972.) 
a lesser degree in fetal plasma (table 2). In the same way, an elevation in maternal plasma magnesium level inducing a threefold increase in plasma concentration, had a poor effect on fetal plasma magnesium (fig. 7). Thus, a change in maternal calcemia of $30 \mathrm{mg} / 100 \mathrm{ml}$ only provoked a change of $3 \mathrm{mg} / 100 \mathrm{ml}$ in fetal calcemia. This buffer action and the observations of Comar (1956) on the placental transfer of calcium 45 strongly suggest a mechanism of active transport across the placenta.

\section{TABLE 2}

Plasma concentrations of calcium and inorganic phosphorus in $\mathbf{2 1 . 5}$ day old rat fetuses from thyroparathyroidectomized (TPTX) or sham-operated mothers (Adapted from Garel and Geloso-Meyer, 1971)

\begin{tabular}{|c|c|c|c|c|c|c|}
\hline & \multicolumn{2}{|c|}{ Calcemia (mg/100 ml) } & \multicolumn{2}{|c|}{ Phosphatemia $(\mathrm{mg} / 100 \mathrm{ml})$} & \multirow{2}{*}{$\begin{array}{c}\text { Fetal weight } \\
(\mathrm{g})\end{array}$} & \multirow{2}{*}{$\begin{array}{l}\text { Fetal para- } \\
\text {-thyroid volume } \\
\left(10^{6} \mu^{3} / g \text { b. w. }\right)\end{array}$} \\
\hline & Mother & Fetus & Mother & Fefus & & \\
\hline $\begin{array}{l}\text { Sham-operated } \ldots \ldots \\
\text { TPTX } \ldots \ldots \ldots \ldots \\
\text { Difference } \ldots \ldots \ldots\end{array}$ & $\mid \begin{array}{c}10.55 \pm 0.12 \\
4.60 \pm 0.33 \\
(7) \\
-5.9 * * *\end{array}$ & $\begin{array}{c}12.10 \pm 0.11 \\
(25) \\
10.52 \pm 0.12 \\
(33) \\
-1.6 * * *\end{array}$ & $\begin{array}{c}5.30 \pm 0.55 \\
(4) \\
10.94 \pm 0.71 \\
(5) \\
+5.6 * *\end{array}$ & $\left|\begin{array}{c}11.40 \pm 0.16 \\
(13) \\
13.29 \pm 0.26 \\
(28) \\
+1.9 * * *\end{array}\right|$ & $\begin{array}{c}5.1 \pm 0.1 \\
(16) \\
3.1 \pm 0.1 \\
(65) \\
-1.9 * * *\end{array}$ & $\begin{array}{c}3.25 \pm 0.29 \\
(10) \\
4.84 \pm 0.36 \\
(10) \\
+1.59 * *\end{array}$ \\
\hline
\end{tabular}

Means \pm S.E.M. ; **P $<0.01 ; * * * P<0.001$.

Surgery of the pregnant females was performed on the third day of gestation.

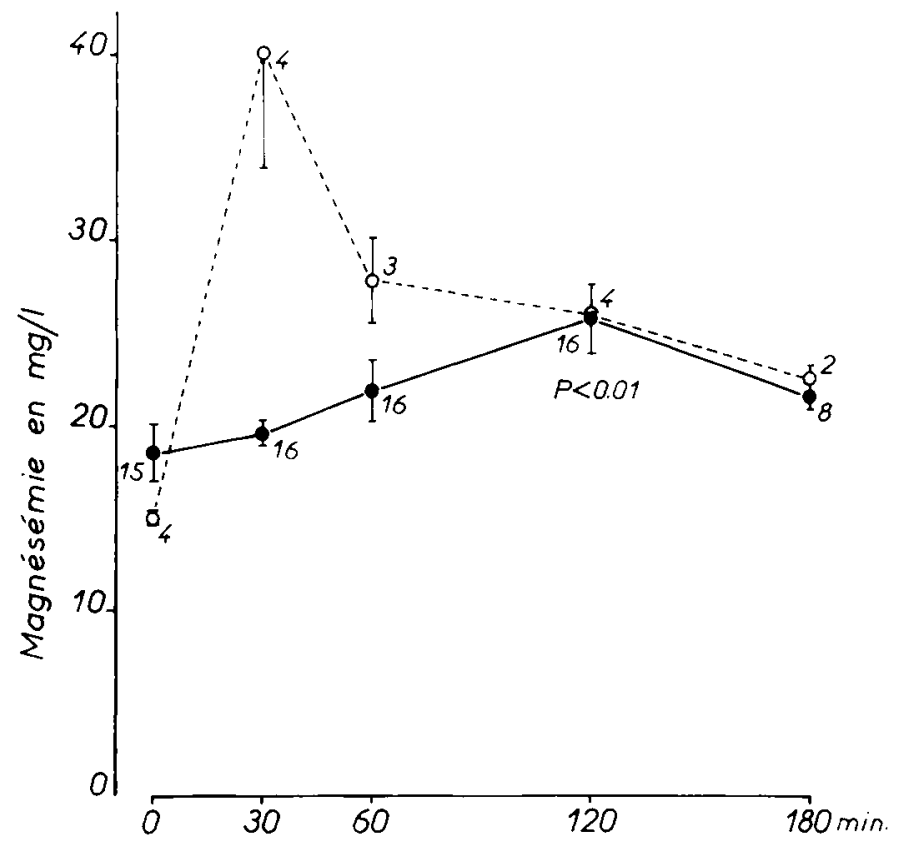

FIG. 7. - Intraperitoneal injection of a single dose of magnesium $(0.15 \mathrm{mEq} / 100 \mathrm{~g} \mathrm{b.} \mathrm{w.)} \mathrm{into} \mathrm{the} \mathrm{mother} \mathrm{;}$ effect on fetal rat magnesemia (means \pm SEM). 
Calcitonin secretion in the fetus.

Two hypotheses may explain the stability of fetal calcemia during maternal hypercalcemia. On one hand, saturation of the active calcium transport across the placenta, not regulated by maternal and/or fetal hormones, would be the main process. On the other hand, maternal and/or fetal CT may be a primary factor by decreasing calcium flux through the placenta. Thus, it is not excluded that the fetus could respond to maternal hypercalcemia by an increase of CT secretion. The purpose of the following experiments is to elucidate these questions by studying fetal CT secretion at the end of gestation. Indirect evidence has been obtained in rat fetus. The intravenous injection of an antiserum (anti-human CT) into 21.5-day old rat fetus slightly increased the plasma calcium concentration $1 \mathrm{~h}$ later (table 3). Milhaud et al. (1972) have shown that this antiserum cross-reacted well with rat CT. The hypercalcemic effect of the antibody confirms the hypothesis of a lack of endogenous CT since it is demonstrated that $C T$ is hypocalcemic in rat fetus. This hormone is probably of fetal origin since 125--porcine CT did not cross the placental barrier (Garel, Milhaud and Sizonenko, 1969) ; it may control the fetal plasma calcium level. CT secretion in the rat fetus at the end of gestation was substantiated by lack of hormone effect in the fetus previously receiving a calcium load (table 4), but in fetus deprived of thyroid by decapitation and

TABLE 3

Effect on plasma calcium concentration of an intravenous injection of anti-human calcitonin antiserum info 21.5 day old rat fetuses

\begin{tabular}{|c|c|c|c|}
\hline \multirow{3}{*}{$\begin{array}{l}\text { Delay after } \\
\text { injection }\end{array}$} & \multicolumn{3}{|c|}{ Calcemia $(\mathrm{mg} / 100 \mathrm{ml})$} \\
\hline & \multirow{2}{*}{ Mother } & \multicolumn{2}{|c|}{ Fetus } \\
\hline & & Vehicle & Antiserum \\
\hline $\begin{array}{l}1 \text { hour } . . . \ldots \ldots \\
2 \text { hours } \ldots \ldots \ldots\end{array}$ & $\begin{array}{c}10.65 \pm 0.27 \\
(4) \\
10.35 \\
(10.60 \& 10.10)\end{array}$ & $\begin{array}{l}12.29 \pm 0.13 \\
(15) \\
11.77 \underset{(4)}{ \pm} 0.26\end{array}$ & $\begin{array}{c}12.92 \pm 0.19 * * \\
(12) \\
11.78 \pm 0.17 \\
(7)\end{array}$ \\
\hline
\end{tabular}

Means $\pm S E M ; * * P<0.01$

TABLE 4

Effect on plasma calcium level of calcitonin administration after a calcium load in 21.5-day old rat fetuses (intact or thyroparathyroidectomized by decapitation) (Adapted from Garel, 1970b)

\begin{tabular}{|c|c|c|c|c|}
\hline & $\begin{array}{l}\text { Delay of } \\
\text { response }\end{array}$ & Vehicle & Calcitonin & Difference \\
\hline $\begin{array}{l}\text { Decapitated fetuses.... } \\
\text { Intact fetuses } \ldots \ldots \text {. }\end{array}$ & $\begin{array}{c}2 \text { hours } \\
(300-180 \mathrm{~min}) \\
2 \text { hours } \\
(300-180 \mathrm{~min})\end{array}$ & $\begin{array}{c}12.40 \pm 0.19 \\
(12) \\
14.30 \pm 0.20 \\
(8)\end{array}$ & $\begin{array}{c}11.09 \pm 0.28 \\
(13) \\
13.96 \pm 0.12 \\
(9)\end{array}$ & $\begin{array}{l}-1.3 \mathrm{mg} / 100 \mathrm{ml} * * * \\
-0.3 \mathrm{mg} / 100 \mathrm{ml}\end{array}$ \\
\hline
\end{tabular}

Means \pm SEM; ***P $<0.001$.

Animals were sampled $300 \mathrm{~min}$. after calcium injection and calcitonin was given $180 \mathrm{~min}$. after calcium injection. 
injected with calcium, the post-administration of CT decreased calcemia (table 4). It was demonstrated in adult rats (Milhaud and Perault-Staub, 1968) that a calcium load induced $C T$ release thus inhibiting bone resorption so that exogenous $C T$ was ineffective ; in thyroidectomized rat, the same treatment induced a decrease in plasma calcium level. The results obtained in rat fetus can be explained by postulating that the fetus is able to secrete CT after calcium stress. Direct evidence of CT secretion has been obtained in sheep fetus using radioimmunoassay. Calcium chloride infusion into sheep fetus 10 days before term increased the CT secretion rate and a linear relationship was found between fetal calcemia and that of fetal CT secretion (Garel, Care and Barlet, 1974). Calcium infusion in the pregnant ewe did not change fetal calcemia (Garel ef al., 1972) ; it induced a sevenfold increase in the jugular venous plasma CT level of the mother, whereas plasma CT concentrations in the fetal thyroid venous blood remained constant (fig. 8). Littledike, Arnaud and Whipp (1972) have also shown that porcine, ovine and bovine fetuses responded to calcium chloride infusion by an increase in plasma immunoreactive CT levels. These results demonstrated that the fetus was not protected against maternal hypercalcemia since its CT secretion was not increased. The lack of correlation between maternal and fetal plasma CT concentrations provides further evidence for the absence of placental transfer of the hormone.

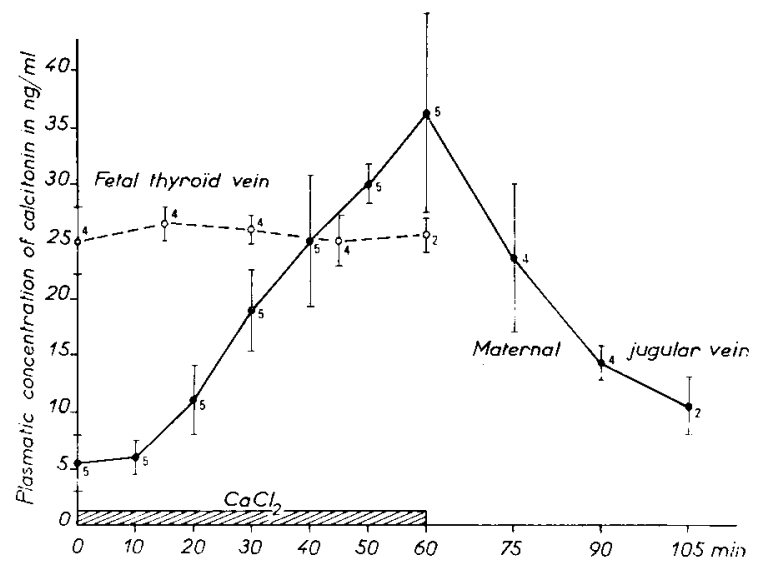

FIG. 8. - Changes in plasmo calcitonin concentrations during calcium infusion into the mother (Means \pm SEM).

(From Garel, Care and Barlet, 1974.)

\section{Calcitonin action on target organs.}

Several lines of evidence indicate that CT is secreted during fetal life, but does CT already act on target organs? Subcutaneous injection of porcine CT (8 MRC $\mathrm{mU} / \mathrm{g}$ body weight) decreased the plasma calcium and inorganic phosphorus levels in rat fetus (20-day old, 21.5-day old), but not before 19.5 days of gestation (Garel, Milhaud and Jost, 1968). A larger dose (140 MRC mU/g body weight of salmon CT) must be given to decrease the fetal plasma magnesium level (Garel and Barlet, 1974). In preliminary experiments, Littledike, Arnaud and Whipp (1972) have shown that 
CT injected intravenously into fetal piglet had no effect on plasma calcium levels in contrast to newborn piglet. In Rhesus monkey fetus, CT induced a triphasic effect with time on the plasma calcium level : a rapid decline, followed by recovery, and then a sluggish decrease (Reynolds, Pitkin and Wezeman, 1975). The intensity of bone resorption at the end of gestation in rat fetus is unknown, but the hypocalcemic effect of CT was probably the result of bone resorption inhibition since in vitro CT inhibits the release of calcium 45 in the culture medium of radius from 19-day old rat fefus (Friedman and Raisz, 1965). We must note that the in vivo effect was very slight after injection of a large dose of CT and indicated poor bone resorption. In the rat fetus, the plasma calcium level decreased after 19.5 days of gestation leading to the conclusion that $C T$ secretion begins at this stage since from the 20th day onwards there is a marked increase in secretory activity of the thyroid « $C$ » cells (Stoeckel and Porte, 1970). Thyroid glands from 19-day old rat fetus in culture secrete an inhibitor of bone resorption in amounts directly proportional to the calcium concentration of the medium (Feinblatt and Raisz, 1971). One of the physiological roles of CT during fetal life would be to promote the mineralization of the fetal skeleton by two different processes : stimulation of the placental calcium pump and/or direct effect on bone by increasing accretion or decreasing resorption. Some results argue against the first hypothesis since Twardock and Austin (1970) have demonstrated in guinea-pig that the presence or absence of the fetus did not affect calcium flux through the placenta. This finding indicates that fetal hormones are not involved in the control of placental transfer of calcium. CT more probably acts on $\mathrm{f} \in \mathrm{tal}$ bones and stimulation of accretion cannot be excluded. In the present state of our knowledge, the role of $\mathrm{CT}$ during fetal life remains obscure.

\section{The Newborn.}

The placental outflow of calcium disappears at birth and the plasma calcium level decreases sharply in newborn rat (Garel, 1969). The hypocalcemic and hypophosphatemic effects of CT were more intense in the newborn rat than in rat fetus (Garel, 1969 ; Garel and Barlet, 1974) ; the newborns were also more sensitive to the hormone since subcutaneous injection of a lower dose (1:5) markedly decreased plasma calcium and inorganic phosphorus concentrations (Garel and Barlet, 1974). The injection of a large dose of $C T$ in the suckling newborn rat had a clearing effect on plasma which was naturally lactescent (Garel, Barlet and Kervran, 1975). The clearing effect of CT was the result of a decrease in plasma lipids, as shown by the decrease in plasma triglyceride concentration (fig. 9). Stomach gavage of triolein- ${ }^{14} \mathrm{C}$ has demonstrated that $3 \mathrm{~h}$ after administration, CT induced a decrease in the weight of the gastric contents and their radioactivity (fig. 10). This observation indicated an inhibition of gastric emptying which was illustrated again by the percentage of triolein- ${ }^{14} \mathrm{C}$ absorbed $3 \mathrm{~h}$ after CT injection (75 p. 100 in controls $4 \mathrm{~h}$ after force-feeding as opposed to $43 \mathrm{p}$. 100 in CT-treated animals). The tissue distribution of radioactivity $4 \mathrm{~h}$ after forcefeeding illustrated the decrease in the absorption of labelled triolein. The distribution of radioactivity in control animals was very high in brown adipose tissue, but low in liver, kidney, muscle and bone ; $3 \mathrm{~h}$ after $\mathrm{CT}$ injection, the distribution of radioacti- 


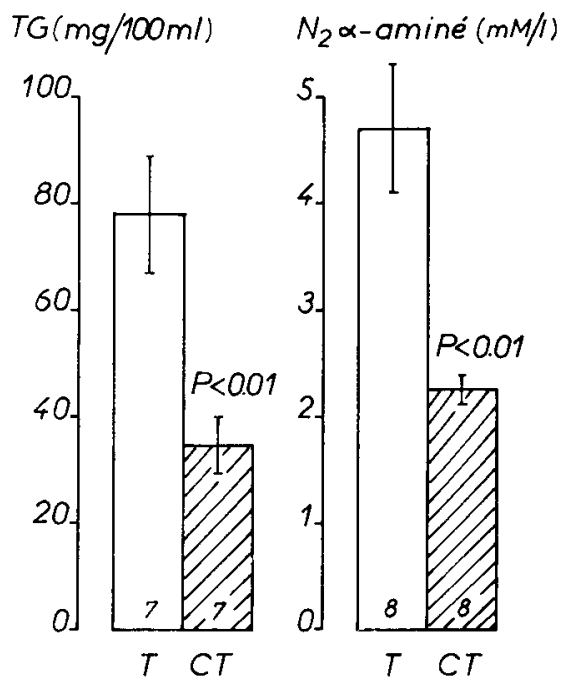

FIG. 9. - Effects on plasma triglycerides (TG) and $\alpha$-amino nitrogen concentrations of calcitonin (CT) $3 \mathrm{~h}$ after subcufaneous injection into 3-day-old suckling rats. $\mathrm{T}=$ control (Means $\pm \mathrm{SEM}$ ).

(Adapted from Garel, Barlet and Kervran, 1975).

c.S.

mg de poids frais

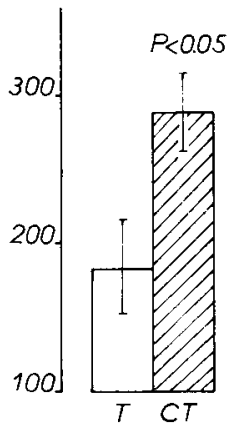

Trioléine ${ }^{14}$ Cdu CS

$10^{6} \mathrm{dpm}$

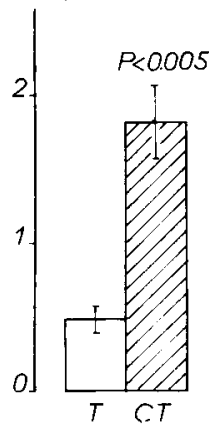

Fig. 10. - Effects on gastric emptying of calcitonin (CT : 3h after subcutaneous injection), 4h after forcefeeding triolein-14 ${ }^{11}$ into 3-day-old suckling rots. $T=$ control animals (Means $\pm S E M$ ).

(Adapted from Garel, Barlet and Kervran, 1975).

vity for each organ studied was less in the CT group than in control animals (Garel, Barlet and Kervran, 1975). In newborn lambs, a physiological dose of porcine CT inhibited the elevation in plasma of total lipid, glucose and amino acid concentrations due to the first suckling period (fig. 11). The hormonal effect was not the result of the quantity of colostrum ingested during the experimental period since it was the same in the three groups. This CT action was not mediated either through the hypocalcemic 

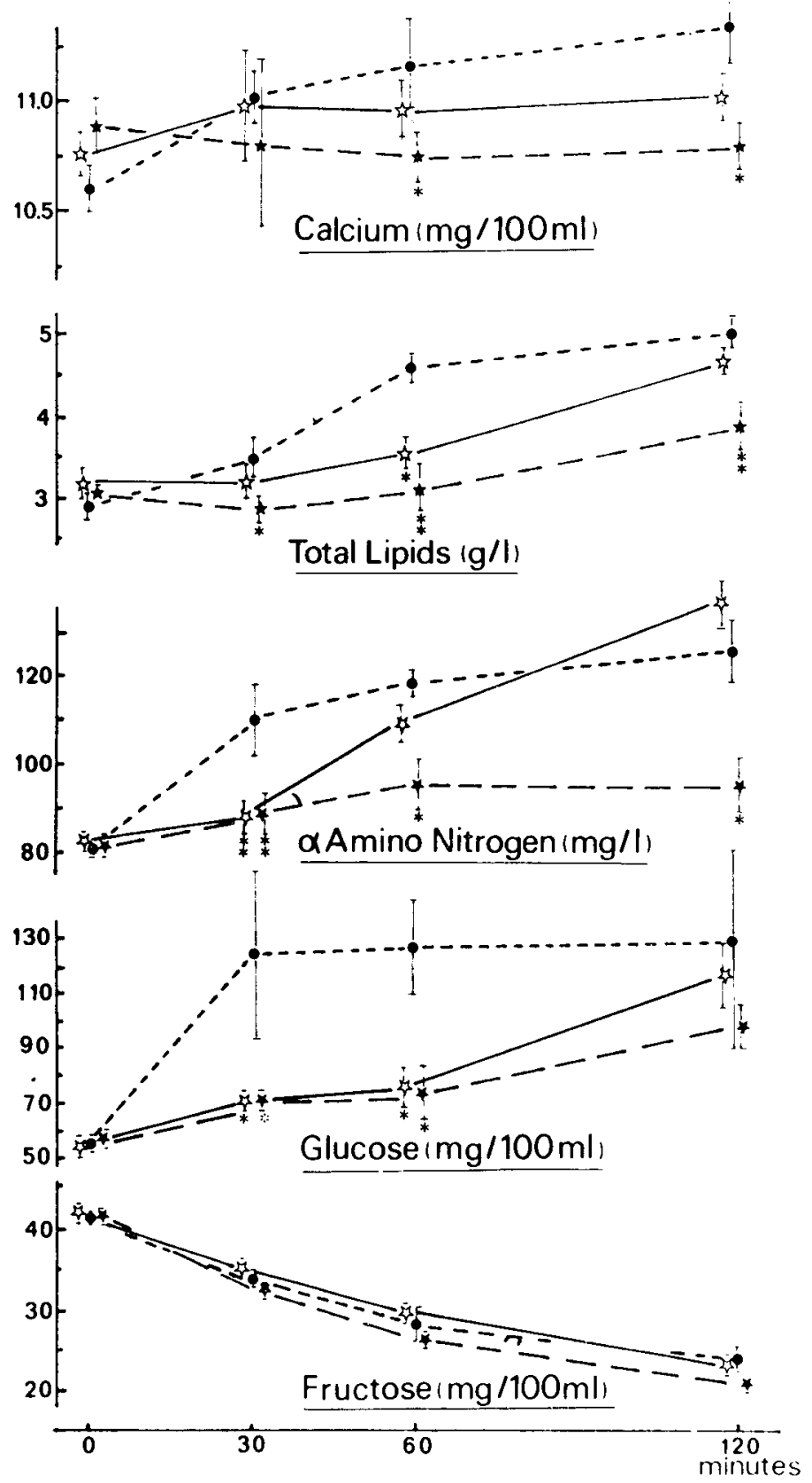

FIG. 11. - Effects of an intravenous injection of calcitonin on plasma calcium, total lipids, $\alpha$-amino nitrogen, glucose and fructose, in newborn lambs. — $30 \mathrm{MRC} \mathrm{mU} / \mathrm{kg} \mathrm{b.} \mathrm{W.} \mathrm{;} \star \star 100 \mathrm{MRC} \mathrm{mU} / \mathrm{kg}$ b. w. ; $--\longrightarrow$ controls. * $\mathrm{P}<0,05 ; * * \mathrm{P}<0.01$.

(From Garel, Barlet and Kervran, 1975.) 
effect of the hormone since $30 \mathrm{MRC} \mathrm{mU} / \mathrm{kg}$ body weight did not change the plasma calcium level. In newborn lambs, fructose is endogenous and disappears rapidly after birth, whereas other nutrients originate from colostrum (Leaf, 1971). The disappearance rate of fructose from the plasma was similar in control and in CT-treated animals and suggests that a reduction in the absorption of lipids, amino acids and carbohydrate is involved in CT action. We suggest that one of the physiological roles of $\mathrm{CT}$ in the newborn involves the regulation of nutrient absorption by gastro-intestinal hormones in an organism which passes from continuous placental feeding in fetal life to a discontinuous supply of nutrients with a lipid-rich milk in post-natal life.

Réunion Groupe Développement INRA/Productions animales Monipellier, 17-18 mai 1977.

Résumé. Les concentrations plasmatiques élevées de calcitonine observées chez la femelle pendant la gestation semblent protéger le squelette maternel contre une déminéralisation excessive au cours de cette période. Il est démontré que le fœetus de mammifère contrôle sa calcémie et que de ce point de vue, il est relativement indépendant des fluctuations de la calcémie maternelle. Le fœus sécrète de la calcitonine et de l'hormone parathyroïdienne, et est autonome à cet égard, mais le rôle de ces hormones au cours de la vie fœetale demeure encore obscur. Un aspect nouveau de la physiologie de la calcitonine chez le nouveau-né est abordé, celui d'une régulation de l'absorption des nutritments par l'intermédiaire de certaines hormones gastro-intestinales.

\section{References}

BAKWIN H., 1937. Pathogenesis of tetany of the newborn. Am. J. Dis. Child., 54, 1211-1226.

BARLET J. P., GAREL J. M., 1975. Physiological role of calcitonin in pregnant goats and ewes, $119-$ 121. In TALMAGE R. V., OWEN M., PARSONS J. A., Calcium regulating hormones. Proc. 5th Parathyroid Conference, Excerpla Med. Amsterdam.

BARLET J. P., GAREL J. M., LEFAIVRE J., DARDILLAT G., 1976. Régulation endocrinienne de la calcémie fœetale chez la Vache et la Brebis. J. Physiol. Paris, 72, 34A.

BAWDEN J. W., WOLKOFF A. S., FLOWERS C. E., 1965. Maternal-fetal blood calcium relationships in sheep. Obstet. Gynecol., 25, 548-552.

BLACK H. E., CAPEN C. C., ARNAUD C. D., 1973. Ultrastructure of parathyroid glands and plasma immunoreactive parathyroid hormone in pregnant cows fed normal and high calcium diets. Lab. Invest., 29, 173-185.

BOUILLON R., DE MOOR P., 1973. Pathophysiological data obtained with a radioimmunoassay for human parathyroid hormone. Ann. Endocr., 34, 657-667.

BRAITHWAITE G. D., GLASCOCK R. F., RIAZUDDIN Sh., 1969. Calcium metabolism in lactating ewes. Br. J. Nutr., 23, 827-834.

BRAITHWAITE G. D., GLASCOCK R. F., RIAZUDDIN Sh., 1970. Calcium metabolism in pregnant ewes. Br. J. Nutr., 24, 661-670.

CARE A. D., COOPER C. W., DUNCAN T., ORIMO H., 1968. The direct measurement of thyrocalcitonin secretion rate in vivo, 417-427. In TALMAGE R. V., BELANGER F., Parathyroid hormone and thyrocalcitonin (Calcitonin). Proc. 3rd Parathyroid Conference, Excerpta Med., Amsterdam.

CARE A. D., PICKARD D. W., GAREL J. M., BARLET J. P., TOMLINSON S., O'RIORDAN J. L. H., 1975. Autonomy of calcium homeostasis in the sheep fœtus. Horm. Metab. Res., 7, 103.

CHEF R., 1969. Métabolisme du calcium chez la ratte en gestation. Etude cinétique par le $45 \mathrm{Ca}$. C. R. Soc. Biol., 163, 541-545.

COMAR C. L., 1956. Radiocalcium studies in pregnancy. Ann. N. Y. Acad. Sci., 64, 251-298.

CUSHARD W. G., CREDITOR M. A., CANTERBURY J. M., REISS E., 1972. Physiologic hyperparathyroidism in pregnancy. J. clin. Endocr. Metab., 34, 767-771. 
DAVID L., ANAST C. S., 1974. Calcium metabolism in newborn infants. J. clin. Invest., 54, $287-296$.

DELIVORIA-PAPADOPOULOS M., BATTAGLIA F. C., BRUNS P. D., MESCHIA G., 1967. Tolal, protein-bound, and ultrafiltrable calcium in maternal and fetal plasmas. Am. J. Physiol., 213, 363-366.

FEINBLATT J. D., RAISZ L. G., 1971. Secretion of thyrocalcitonin in organ culture. Endocrinology, 88, 797-804.

FIELD A. C., SUTTLE N. F., 1967. Retention of calcium, phosphorus, magnesium, sodium and potassium by the developing sheep foetus. J. Agric. Sci. Camb., 69, 417-423.

FRIEDMAN J., RAISZ L. G., 1965. Thyrocalcitonin : inhibitor of bone resorption in tissue culture. Science, 150, 1465-1466.

GAREL J. M., 1969. Action hypocalcémiante et hypophosphatémiante de la thyrocalcitonine chez le rat avant et après la naissance. C. R. Acad. Sci. Paris, série D, 268, 1525-1528.

GAREL J. M., 1970a. Effet de l'injection d'un sérum « anti-parathormone » chez le fcetus de rat. C. R. Acad. Sci. Paris, série D, 271, 2364-2366.

GAREL J. M., 1970b. Action de la calcitonine après surcharge calcique chez le fœetus de rat entier ou décapité. C. R. Acad. Sci. Paris, série D, 271, 1560-1563.

GAREL J. M., 1975. Assessment of fetal rat parathyroid gland activity during hypocalcemia induced by EDTA. Biol. Neonate, 27, 115-120.

GAREL J. M., BARLET J. P., 1974. The effects of calcitonin and parathormone on plasma magnesium levels before and after birth in the rat. J. Endocr., 61, 1-13.

GAREL J. M., BARLET J. P., KERVRAN A., 1975. Melabolic effects of calcitonin in newborns. Am. J. Physiol., 229, 669-675.

GAREL J. M., CARE A. D., BARLET J. P., 1974. A radioimmunoassay for ovine calcitonin : an evaluation of calcitonin secretion during gestation, lactation and fœetal life. J. Endocr., 62, 497-509.

GAREL J. M., DUMONT C., 1972. Distribution and inactivation of labeled parathyroid hormone in rat fetus. Horm. Metab. Res., 4, 217-221.

GAREL J. M., DUMONT C., BARLET J. P., GARE A. D., 1972. Fetal-maternal plasma calcium relationships in rat and sheep. J. Physiol. Paris, 64, 387-398.

GAREL J. M., GELOSO-MEYER A., 1971. Hyperparathyroïdisme fotal chez le rat consécutif à un hypoparathyroïdisme maternel. Europ. J. clin. biol. Res., 16, 174-178.

GAREL J. M., MILHAUD G., JOST A., 1968. Action hypocalcémiante ef hypophosphatémiante de la thyrocalcitonine chez le fœetus de rat. C. R. Acad. Sci. Paris, série D, 269, 1785-1787.

GAREL J. M., MILHAUD G., SIZONENKO P., 1969. Thyrocalcitonine et barrière placentaire chez le rat. C. R. Acod. Sci. Paris, série D, 269, 1785-1787.

GAREL J. M., PIC P., 1972. Evolution of phosphatemia in the rat fetus during the late stages of gestation. Biol. Neonate, 21, 369-374.

GAREL J. M., PIC P., JOST A., 1971. Action de la parathormone chez le fœtus de rat. Ann. Endocr 32, 253-269.

GAREL J. M., SAVAJOL H., BARLET J. P., 1976. Plasma immunoreactive calcitonin levels in pregnant ewes and their lambs. Biol. Neonate, 28, 207-218.

GRAHAM R. W., SCOTHORNE R. J., 1970. Calcium homeostasis in the foetal guinea pig. Quart. J. exp. Physiol., 55, 44-53.

GRAHAM R. W., PORTER G. P., 1971. Fetal-maternal plasma calcium relationships in the rabbit. Quart. J. exp. Physiol., 56, 160-168.

HEANEY R. P., SKILLMAN T. G., 1971. Calcium metabolism in normal human pregnancy. J. clin. Endocr. Metab., 33, 661-670.

JOST A., MOREAU G., FOURNIER C., 1960. Date et ordre d'apparition des premiers centres d'ossification chez le fotus de rat normal ou soumis au propylthiouracile. Arch. Anat. micr. Morphol. exp., 49, 431-458.

KONOPKA P., KLOTZ H. P., DELORME M. L., 1971. L'état calcitoninique au cours de la gravidité, 253-269. In KLOTZ H. P., Problèmes actuels d'endocrinologie ef de nutrifion, série 15, Expansion Scientifique Française, Paris.

KRUKOWSKI M., LEHR D., 1963. Parathyroid hormone and the placental barrier. Arch. int. Pharmacodyn., 146, 245-265.

LEAF L. M. F., 1971. Digestion and metabolism of earbohydrates in the foetal and neonatal ruminant. Proc. Nutr. Soc., 30, 236-243. 
LEWIS P., RAFFERTY B., SHELLEY M., ROBINSON C. J., 1971. A suggested physiological role of calcitonin : the protection of the skeleton during pregnancy and lactation. J. Endocr., 49, IX-X.

LITTLEDIKE E. T., ARNAUD C. D., WHIPP C. S., 1972. Calcitonin secretion in ovine, porcine and bovine fetuses. Proc. Soc. exp. Biol. Med. 139, 428-433.

MILHAUD G., PERAULT-STAUB A. M., 1968. Surcharge en calcium, thyrocalcitonine et catabolisme osseux. C. R. Acad. Sci. Paris, série D, 266, 1410-1413.

MILHAUD G., THARAUD D., JULLIENNE A., MOUKHTAR M. S., 1972. Radioimmunoassay of rat calcitonin, 380-385. In TAYLOR S., Endocrinology 1971, Proceed. 3rd int. Symp., W. Heinemann Medical Books, London.

PIC P., 1968. Maintien d'une calcémie fœetale élevée en l'absence des parathyroïdes maternelles et foetales, chez le rat. C. R. Soc. Biol., 162, 1043-1047.

PIC P., 1969. Evolution de la calcémie foetale du rat en fin de gestation. C. R. Soc. Biol., 163, 1033-1038.

PIC P., 1973. Rôle des parathyroïdes fœetales dans la régulation de la calcémie et de la phosphatémie du fœitus de rat. Ann. Endocr., 34, 621-645.

PIC P., MANIEY J., JOST A., 1965. Facteurs endocriniens réglant la calcémie fœetale. Indications sur le rôle des parathyroïdes. C. R. Soc. Biol., 159, 1274-1277.

RADDE I. C., PARKINSON D. K., HOFFKEN B., 1971. Ionized calcium in the healthy and diseased neonate. Proc. XIII int. Congr. Pediatr., 363-365.

REYNOLDS W. A., PITKIN R. M., WEZEMAN F. H., 1975. Calcitonin effects in primate pregnancy. Am. J. Obstet. Gynec., 122, 212-218.

SALMI I., 1954. On the influence of anoxia on plasma calcium. Experimental and clinical observations. Ann. Paediat. Fenn., 1, suppl. 2, p. 1-100.

SAMAAN N. A., WIGODA C., CASTILLO S. G., 1974. Human serum calcitonin and parathyroid hormone levels in the maternal, umbilical cord blood and post-partum, 364-372. In TAYLOR S. Endocrinology 1973, Proceed. 4th int. Symp., W. Heinemann Medical Books, London.

SHAMI Y., RADDE I. C., 1971. Calcium stimulated ATPase of guinea-pig placenta. Biochim. biophys. Acta, 249, 345-352.

SMITH F. G., ALEXANDER D. P., BUCKLE R. M., BRITTON H. G., NIXON D. A., 1972. Parathyroid hormone in foetal and adult sheep : the effects of hypocalcaemia. J. Endocr., 53, 339-348.

STOECKEL M. E., PORTE A., 1970. Origine embryonnaire ef différenciation sécrétoire des cellules à calcitonine (cellules C) dans la thyroïde foetale du rat. Z. Zellforsch. mikrosk. Anat., 106, $251-268$

SYMONDS H. W., MANSTON R., PAYNE M., SANSOM B. F., 1966. Changes in the calcium and phosphorus requirements of the dairy cow at parturition with particular references to the amounts supplied to the foetus in utero. Br. Vet. J., 122, 196-200.

TAYLOR T. G., LEWIS P. E., BALDERSTONE O., 1975. Role of calcitonin in protecting the skeleton during pregnancy and lactation. J. Endocr., 66, 297-298.

TWARDOCK A. R., AUSTIN M. K., 1970. Calcium transfer in perfused guineapig placenta. Am. J. Physiol., 219, 540-545.

WASSERMAN R. H., COMAR C. L., NOLD M. M., LENGEMANN F. W., 1957. Placental transfer of calcium and strontium in the rat and rabbit. Am. J. Physiol., 189, 91-97. 